\title{
ANTARCTIC ICE-SHELF BOUNDARIES AND ELEVATIONS FROM SATELLITE RADAR ALTIMETRY
}

\author{
by
}

H.J. Zwally

(Laboratory for Oceans, NASA Goddard Space Flight Center, Greenbelt, MD 20771, U.S.A.)

S.N. Stephenson

(Science Applications Research, NASA Goddard Space Flight Center, Greenbelt, MD 20771, U.S.A.)

\author{
R.A. Bindschadler
}

(Laboratory for Oceans, NASA Goddard Space Flight Center, Greenbelt, MD 20771, U.S.A.)

and

R.H. Thomas

(Royal Aircraft Establishment, Farnborough, U.K.)

\begin{abstract}
As part of a systematic analysis of Seasat radar altimetry data to obtain Antarctic ice fronts and ice-shelf elevations north of lat. $72{ }^{\circ} \mathrm{S}$., Fimbulisen (between long. $12^{\circ} \mathrm{W}$. and $08^{\circ} \mathrm{E}$.) and the Amery Ice Shelf (around long. $72^{\circ} \mathrm{E}$.) are mapped. Interactive computer analysis is used to examine and correct the altimetry range measurements and derive the ice-front positions. Surface elevations and ice-front positions from radar altimetry are compared with ice fronts, ice rises; crevasse zones, and grounding lines identified in Landsat imagery. By comparison of the visible features in imagery and the computer-contoured elevations from radar altimetry, the radar-elevation mapping on some ice rises is confirmed, but some spurious contours are also identified. During the interval between the 1974 Landsat imagery and the 1978 radar altimetry, the central part of the Amery Ice Shelf front advanced $1.5 \pm 0.6 \mathrm{~km} / \mathrm{a}$, which is in agreement with the ice-velocity measurements of $1.1 \pm$ $0.1 \mathrm{~km} / \mathrm{a}$ (Budd and others 1982), suggesting negligible calving in the central part of the ice shelf. The undulating surface and small mean slope from the grounding line to about lat. $70^{\circ} \mathrm{S}$. suggest a zone of partial grounding similar to Rutford Ice Stream. On Fimbulisen, some previously unmapped ice rises are identified. The ridge of the Jutulstraumen ice tongue is shown to be about $20 \mathrm{~m}$ above the surrounding ice and laterally expanding as it flows northward to the ice front. Icebergs within the sea ice and a zone of shore-fast ice are also identified with the same technique used to map the ice-shelf front.
\end{abstract}

\section{INTRODUCTION}

Since 1975, satellite radar altimeters designed for measurement of ocean-surface topography have been used for measuring ice-sheet topography and for deducing other features of the ice configuration and reflective properties of the surface (e.g. Brooks and others 1978, Thomas and others 1983, Zwally and others 1983[a], Bindschadler 1984, Partington and others 1987). The use of satellite radaraltimeter data for glaciological studies has required the analysis of each radar wave form (corresponding to a range measurement every $1 / 10 \mathrm{~s}$ ) to obtain the surface elevation at $670 \mathrm{~m}$ intervals (Martin and others 1983). Also, the effects of regional surface slopes and surface undulations has had to be considered, because the altimeter tends to measure the range to the closest surface location within about a $10 \mathrm{~km}$ radius of the sub-satellite point (e.g. Brenner and others 1983, Gundestrup and others 1986).

Due to limitations in the width of the range window of the altimeter and its ability to change the position of the window as the range from the altimeter to the surface changes, abrupt changes in elevation at ice fronts, and even the changes in range due to surface undulations, of ten cause the altimeter to lose track of the range between measurements (e.g. Martin and others 1983). After loss of track, several seconds or more of data were not obtained while the altimeter searched through a much larger range window looking for a reflected signal from the surface. Consequently, substantial gaps occurred in the data record in regions of large undulations or at abrupt changes in elevation.

Nevertheless, Thomas and others (1983) showed that the margin of large ice sheets can be mapped using the characteristics of the Seasat altimeter range measurements just before the altimeter lost track in the vicinity of an abrupt change in elevation. They demonstrated that the altimeter continued to measure the slant range back to the sea ice in front of the sea-ice/ice-shelf boundary while passing from sea ice to ice shelf. A short section of the front, sometimes $10 \mathrm{~km}$ long, could be mapped at each crossing of a boundary, usually followed by a data gap of $10-20 \mathrm{~km}$. After loss of track, the altimeter range search would find the reflected signal from the higher elevation of the ice shelf, and measurement of surface elevation would resume. A similar situation occurred in reverse during crossings from ice shelf to sea ice. The method has now been applied to about 400 orbits of the Seasat data set in the Antarctic, and in this paper some of the results for the Amery Ice Shelf and Fimbulisen are described.

\section{METHOD}

To process the large volume of data, an analysis procedure was developed on an HP9845C interactive computer. The altimeter wave-form shapes and intensities and the indicated heights, which had been previously range-corrected by automated computer re-tracking (Martin and others 1983), were interactively reviewed. The automatic computer re-tracking algorithm had also been modified to re-track the sharply peaked wave forms characteristic of the specular reflections from sea ice. The program allowed the operator to select a new re-track point, when needed, to 

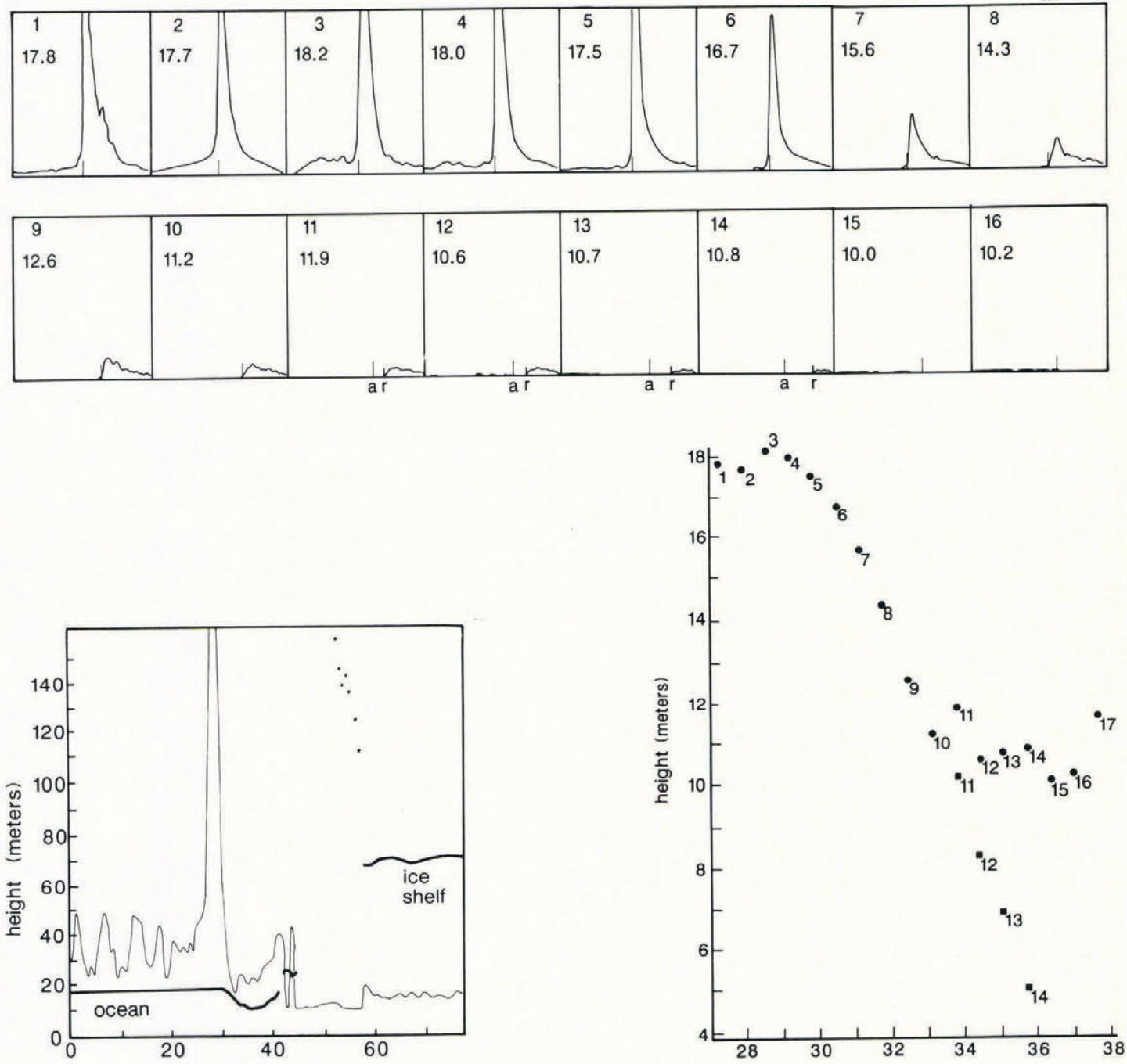

distance from begining of ground track $(\mathrm{km})$

distance in $\mathrm{km}$ from begining of ground track

Fig.1. (a) Sequence of radar-altimeter wave forms at an ice-front crossing, from sea ice to ice shelf, selected by finding the apparent (false) lowering in the sea surface shown in Fig.lb. The top left-hand number in the sequence is also used in Fig.1c. The lower numbers indicate the level of the sea-ice surface with respect to a reference ellipsoid. The thin vertical tick mark labeled "a" shows the computer-calculated half-peak power position of the ramp. The thick tick mark labeled " $r$ " shows the interactively selected position for the weaker returns. (b) Indicated surface heights (dark line) with respect to an ellipsoid and the relative intensity (light line) of the reflected radar signal before the ramp of the altimeter wave forms. (c) Uncorrected indicated heights at points corresponding to wave forms in (a) and corrected indicated heights for points 11 to 14.

determine the correct range (indicated height). In particular, interactive re-tracking is often needed for the weaker returns from the sea-ice/ice-sheet boundary, particularly at the larger distances from the boundary. The interactive program also calculates and plots the envelope of possible reflectors on a surface map for each boundary crossing and selects a set of reflecting points, which are reviewed by the operator.

A typical set of wave forms while traversing an ice-sheet margin is shown in Fig.la. The segment of the record to be examined is first identified and selected by plotting the indicated heights along a longer section of the orbit, as shown in Fig.1b. The intensity of the wave form forward of the main wave-form ramp is also plotted to assist in the identification of a boundary crossing, which is characterized by an increase in intensity caused by early reflection from the part of the altimeter wave front intersecting the ice-shelf surface forward of the altimeter (Thomas and others 1983). Here, several typical features of a boundary crossing are evident. For the first $30 \mathrm{~km}$ from the beginning of this segment, there is sea ice at sea-level After $55 \mathrm{~km}$, there is ice shelf, $50 \mathrm{~m}$ above the level of the sea ice. At the $30 \mathrm{~km}$ point, an apparent (false) lowering of the sea surface begins (shown in greater detail in Fig.1c), due to the increasing slant range to the reflecting sea-ice area near the ice front. After the drop-off in elevation, the wave-form signal becomes lost in the noise, and the altimeter range lock is lost. Loss of lock initiates a signal search, and range lock is regained on the ice shelf at the $55 \mathrm{~km}$ point.

Referring to Fig.1a and c, it can be seen that the on-board tracker and the re-tracking algorithm find it increasingly difficult to identify a wave-form ramp (sharp rise in reflected radar signal strength), as the slant range increases and the intensity decreases. It is also obvious that wave forms 11 through 16 were not properly re-tracked by the automatic algorithm, as indicated by the automatic re-track point (a) in Fig.1a. For the purpose of mapping the sea-ice/ice-shelf boundary, the chosen re-tracking point on the wave-form signal is where the rising ramp of the return signal begins to emerge from the noise. Wave forms 11 to 14 have adequate signal above the noise and are interactively re-tracked to provide four more range measurements to the sea ice, thereby extending the observed 


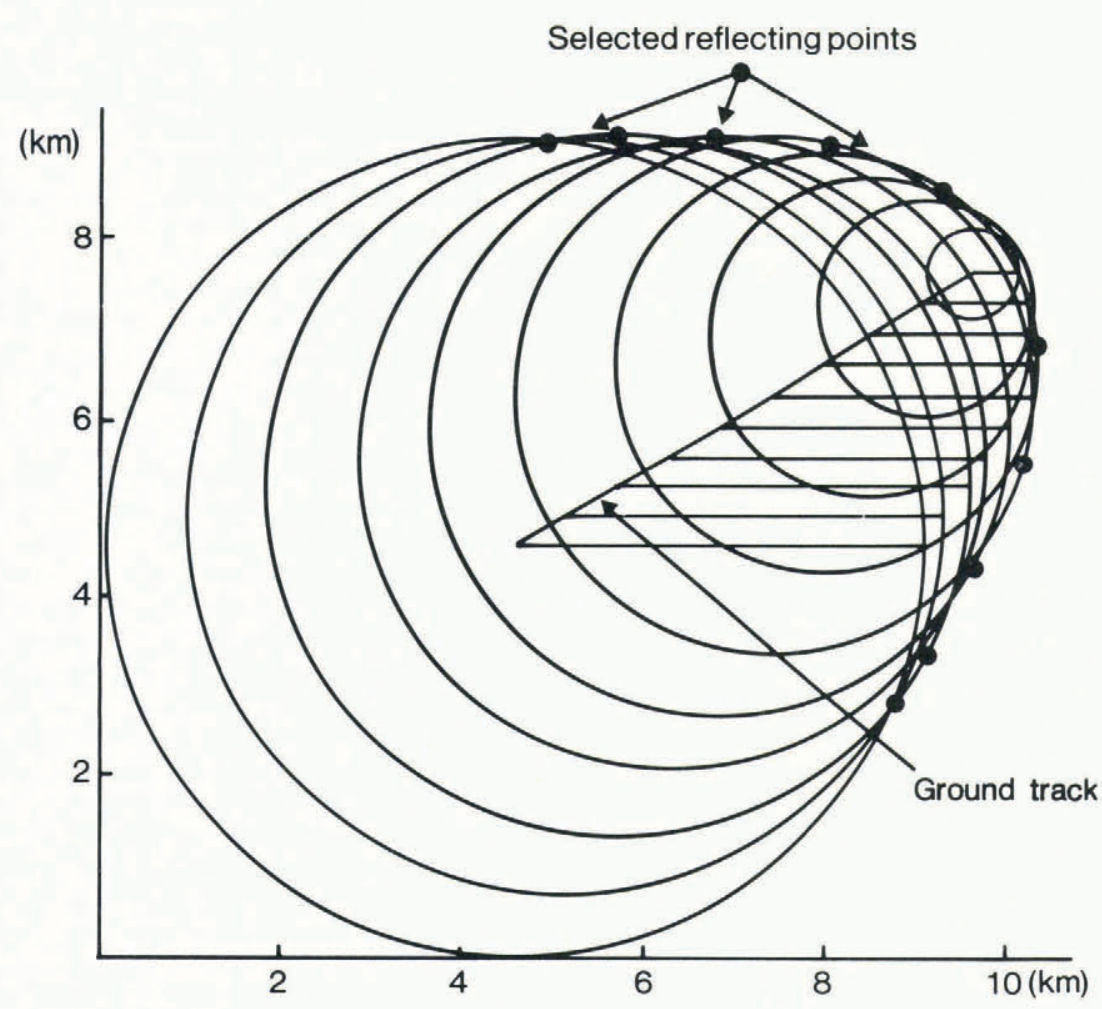

Fig.2. Sequence of circles representing the intersection of the slant range, derived from the corrected indicated heights for points 5 to 14 of Fig.1, with the Earth's surface. Dots between the intersections of the circles are chosen to represent the reflecting points, on the sea ice near the ice front, that correspond to the re-tracked radar signal. Series of dots form the arms of a "V" with left-right ambiguity resolved by plotting a series of "V"s from nearby crossings.

segment about $2 \mathrm{~km}$. Subsequently, no useful returns were obtained between 36 and $58 \mathrm{~km}$, at which point the profiling of the ice-shelf surface begins. It should also be noted that just prior to regaining range lock around the $58 \mathrm{~km}$ point, some erroneous elevation measurements $(>100 \mathrm{~m})$ are included in the computer re-tracked data set. Most of such erroneous elevations have been eliminated from the data set used for gridding and contouring elevations by visual editing of plots of the wave forms and the re-tracking parameters.

Using the sequence of corrected indicated heights, which represent the sequence of slant ranges back to the boundary crossing, a set of circles is then drawn representing the envelope of possible reflecting points at the boundary, as shown in Fig.2. The circles represent the intersection on the Earth's surface of a cone defined by the slant range and the height of the satellite above the surface. The sequence of heights is obtained by extrapolating the geoid inland from the measurements over sea ice. The mid-points between intersections of the circles are chosen as the average reflecting points at the boundary. A left-right ambiguity occurs at each crossing, with the mirror images of the two possible boundaries forming two arms of a "V". In many cases, the left-right ambiguity is resolved when several nearby crossing points are plotted and two arms of partially overlapping "V"s line up with each other. Where an orbit is isolated from its neighbors, the general direction of the front as indicated by the neighboring "V"s can help resolve the ambiguity, because the arms of the " $\mathrm{V}$ " represent steps in a known direction and usually one of the arms fits the general picture better than the other.

During some boundary crossings, the gain of the receiver is significantly less than in the case shown here and the elevation drop-off is not clearly defined. However, the power of the return decreases sharply at the boundary, which corresponds to the beginning of the drop-off, as shown by wave forms 5,6 , and 7 in Fig.la. A similar sharp decrease in the peak power is observed in the low-gain cases, and where this occurs a boundary crossing point is also mapped.

Thomas and others (1983) also described the reverse situation, when the satellite path traverses from ice sheet or ice shelf to sea ice. They showed that a similar drop-off of the indicated surface elevation occurs. However, a difficulty is encountered in this case, because the ice-shelf surface is not as flat as the sea-ice surface and, consequently, the changes in elevations over ice-shelf undulations sometimes reduce the drop-off or resemble the change in indicated height typically seen at such boundaries. Therefore, it is of ten difficult to judge where the decrease in elevation due to undulations stops and the drop-off caused by slant-range measurement backward to the ice-shelf front begins. Also, because the ice-shelf surface near the front tends to be tilted seaward, a marked drop-off in the signal strength from the ice-shelf reflection usually does not occur after the spacecraft passes seaward over the boundary. However, since the sea ice is lower in elevation than the ice shelf (i.e. greater range from the satellite) and the altimeter tracking circuit is adjusting to the increasing slant range backward to the ice shelf, the altimeter sometimes picks up the sea-ice return without loss of track, in contrast to the usual loss of track during a sea-ice to ice-shelf transition. Ice-front positions are mapped for these ice-shelf to sea-ice transitions but the location is usually not as well defined.

\section{AMERY ICE SHELF}

The result of mapping the Amery Ice Shelf front by Seasat radar-altimeter data obtained during July-October 1978 is shown in Fig.3. Seventeen orbital paths cross the 


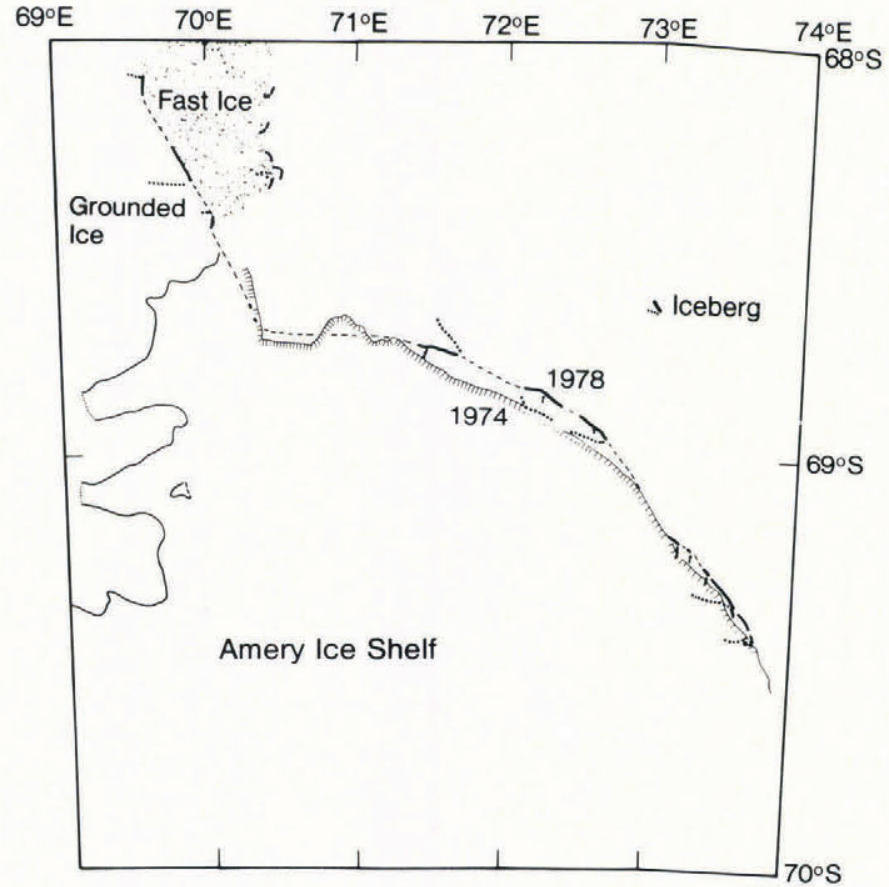

Fig.3. Amery Ice Shelf front in 1978 derived from radar altimetry compared with ice front sketched from Landsat imagery taken in 1974. Also shown is an area of fast sea ice and the seaward edge of the grounded ice sheet north-west of the ice shelf.

front of the main part of Amery Ice Shelf and one orbit (No. 545) intersects the edge three times giving $30 \mathrm{~km}$ of ice front. Both arms of the "V"s are shown, with the preferred arm indicated by the heavier line. Overall, about $40 \%$ of the $170 \mathrm{~km}$ front is mapped. Thomas and others (1983) estimated the errors of this method to be in the range of $\pm 0.1-1.0 \mathrm{~km}$, depending on the distance of the satellite from the ice front when the slant range is obtained. Although the actual accuracy of the radar-mapped boundary is difficult to establish, it is roughly estimated to be $\pm 1 \mathrm{~km}$

Fig. 3 also shows the ice front from Landsat imagery obtained in 1974, 4 years before the Seasat data. The images are the same as those used by Brooks and others (1983) in their illustration with surface contours of the Amery Ice Shelf, also from Seasat radar altimetry. The superimposed geographic grid from their illustration is used here to match the Landsat image with the altimeter-derived edge. Brooks and others (1983) assigned latitudes and longitudes to their mosaic by transferring coordinates of nunatak features from the 1: 1000000 topographic map of the Amery Ice Shelf produced by the Australian Division of National Mapping in 1971. The accuracy of the Landsat-derived ice-front position is roughly estimated to be about $\pm 2 \mathrm{~km}$.

Along the eastern part of the ice shelf, several of the radar-derived ice-front positions and the Landsat ice front are in good agreement. For the central part of the ice shelf, there is a $6-7 \mathrm{~km}$ difference in the ice-front positions obtained by the two methods at an interval of 4 years. Allowing for the uncertainties in each of the lines and the 4 year period between the observations, the difference in positions indicates an advance of the ice front at a rate of $1.5 \pm 0.6 \mathrm{~km} / \mathrm{a}$. This rate of advance is in agreement with the ice-shelf velocity measurement of $1.1 \pm 0.1 \mathrm{~km} / \mathrm{a}$ by Budd and others (1982), suggesting little or no calving of the central part of the ice front during this period.

Segments of the seaward margin of the grounded ice sheet north-west of the ice shelf are also mapped, demonstrating the application of the radar margin-mapping technique for grounded coastal margins as well as floating ice fronts. A single edge point located in the ocean at long. $73^{\circ} \mathrm{W}$., about $40 \mathrm{~km}$ north of the ice front, is interpreted as an iceberg.
A number of edge features are also located in the ocean in the north-western corner of Fig.3. Here, several edge points line up, and they are interpreted as the edge of fast sea ice with a thick snow cover. The reflecting surface is about $2 \mathrm{~m}$ higher inside this boundary, the altimeter wave form is characteristic of reflection from a firn surface rather than the peaked specular return characteristic of sea ice, and the surface appears to be about $1-2 \mathrm{~m}$ above the sea ice to the east. Also, the edge does not vary in position noticeably during the period of the altimeter measurements, as it would if it were a polynya with possibly non-specularly reflecting sea-ice types. Furthermore, the area is in a location of highly consolidated sea ice at this time of year (Zwally and others 1983[b]), and the US Navy-NOAA maps indicated fast ice there the previous summer.

In addition to the new estimate of the ice-shelf front, automated contouring of the altimeter data has been carried out following the method described by $Z$ wally and others (1983[a]). To summarize the procedure, the data have been re-tracked using the method described by Martin and others (1983), followed by visual editing of the re-tracked wave forms to eliminate additional invalid data. Radial adjustment of the orbits (r.m.s. minimization of height difference at orbital intersections over the ocean) and correction for the slope-induced error due to off-nadir reflections (Brenner and others 1983) have not yet been carried out on the Antarctic data set. The slope-induced error is small on the ice shelf due to the small surface slopes, but radial orbit errors up to several meters remain in some of the data. The data are then used to produce a surface on a regular grid at $5 \mathrm{~km}$ spacing, and then contoured at $2 \mathrm{~m}$ intervals over the ice shelf and $20 \mathrm{~m}$ intervals over the ice sheet. The gridding procedure also eliminates data that are more than 3 sigma from the surface fitted to the data in the vicinity of a grid point to obtain the value at the grid point. The elevations shown are referenced to sea-level by subtracting the GEM-10B (Goddard Earth Model version 10B) geoid from the ellipsoid-referenced altimeter elevations shown in Fig.1b.

The ice-shelf contours shown in Fig.4 basically reproduce the main features shown by Brooks and others (1983), although data from 40 additional orbits are used. Over the ice sheet surrounding the ice shelf, altimeter tracking was frequently lost, resulting in a sparse data set at the change in slope inside the grounding line and in the region to the west of the ice shelf. Since no orbit adjustment has been made, linear features in the direction of the satellite tracks (predominately east-west in these regions) with several meters relief need to be viewed with caution (cf. next section).

One significant difference between the map of Brooks and others (1983) and Fig.4 is the delineation of a region of the ice shelf with an undulating surface and small mean slope for about $200 \mathrm{~km}$ below the grounding line (from about lat. $72^{\circ}$ to $70^{\circ} \mathrm{S}$.). If the ice shelf were freely floating, such a pattern would not be expected. The characteristics of this region suggest a zone of patchy grounding of the ice shelf, similar to that observed on enhanced Landsat imagery of Rutford Ice Stream (Doake and others in press).

Another new feature in the contour map is a small topographic high point located at lat. $69^{\circ} 15^{\prime} \mathrm{S}$. , long. $71^{\circ} 30^{\prime} \mathrm{E}$. about $40 \mathrm{~km}$ from the ice front. Four orbits define this feature, and it is interesting to speculate whether it is an ice rumple forming on a shoal which is helping to stabilize the ice front. However, the surface expression is small and the existence of this feature needs to be examined after the radial-orbit adjustments have been applied to the data.

\section{FIMBULISEN}

A similar analysis has been carried out for the altimeter data over Fimbulisen. Fig.5 shows the sub-satellite ground tracks in this area, with the gaps indicating loss of track. The data were computer re-tracked, but again, no radial-orbit adjustment has been applied. The contour plot is given in Fig.6. Residual radial errors in some of the orbits produce false linear features extending, for example, over the ocean from around lat. $69^{\circ} \mathrm{S}$., long. $0^{\circ} \mathrm{E}$. towards 


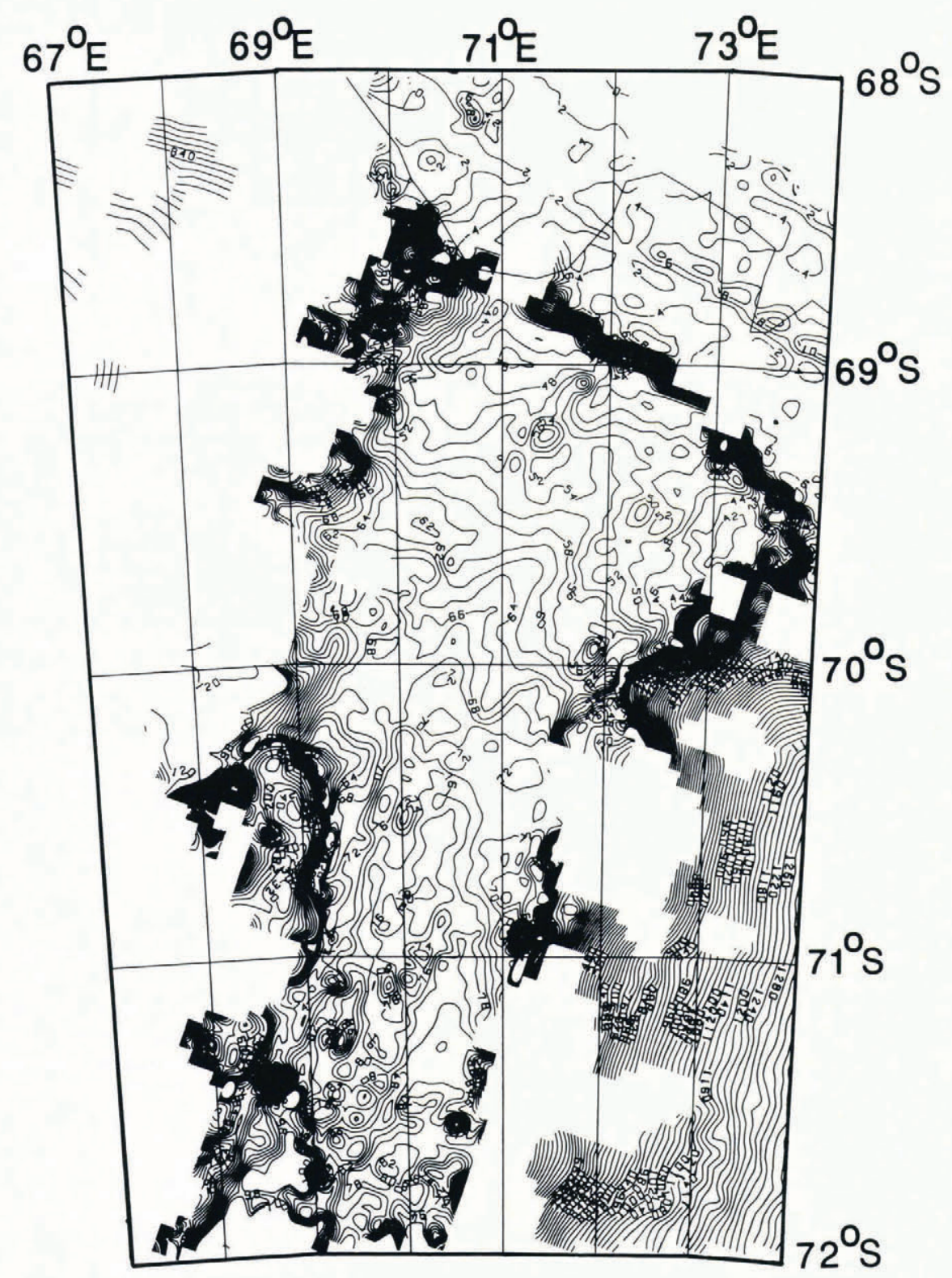

Fig.4. Surface elevations of the Amery Ice Shelf and adjacent grounded ice from Seasat radar altimetry, showing undulating surface with small mean slope extending from vicinity of grounding line near lat. $72^{\circ} \mathrm{S}$. to around $70^{\circ} \mathrm{S}$.

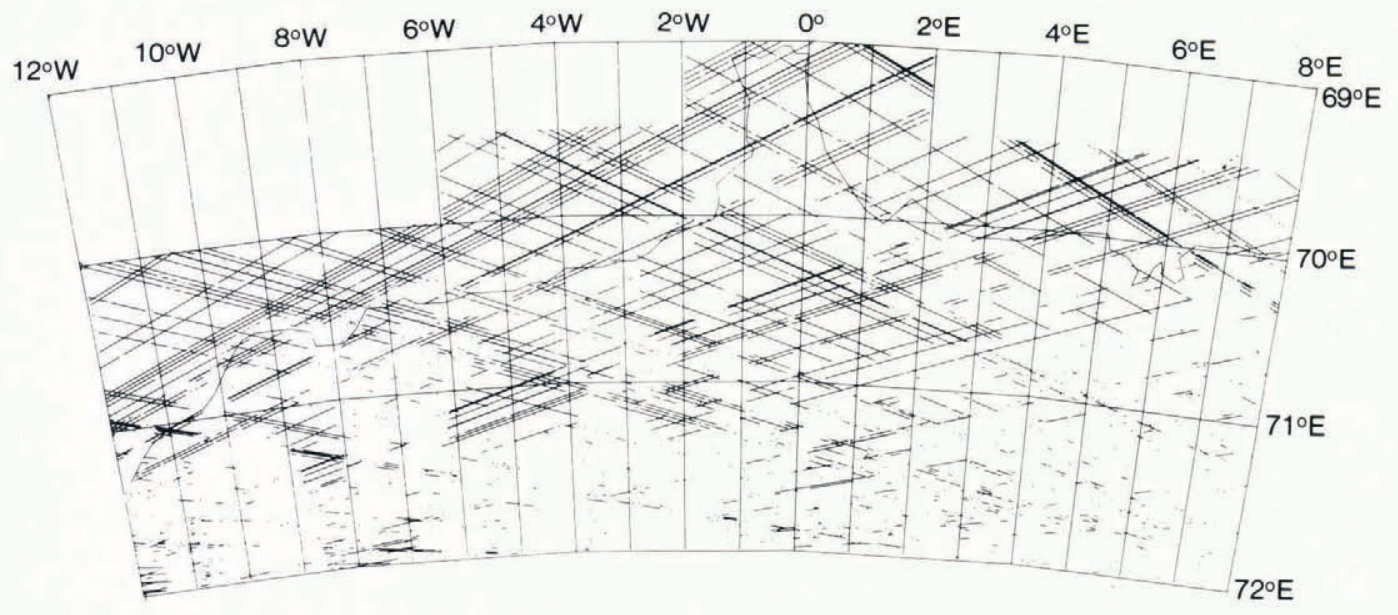

Fig.5. Seasat ground tracks in the vicinity of Fimbulisen, showing loss of track in places of large surface slope and after abrupt elevation change over the ice-shelf front. Solid line is continental boundary from 1965 AGS map prior to the 1967 calving of Trolltunga at long. $0^{\circ} \mathrm{W}$. 


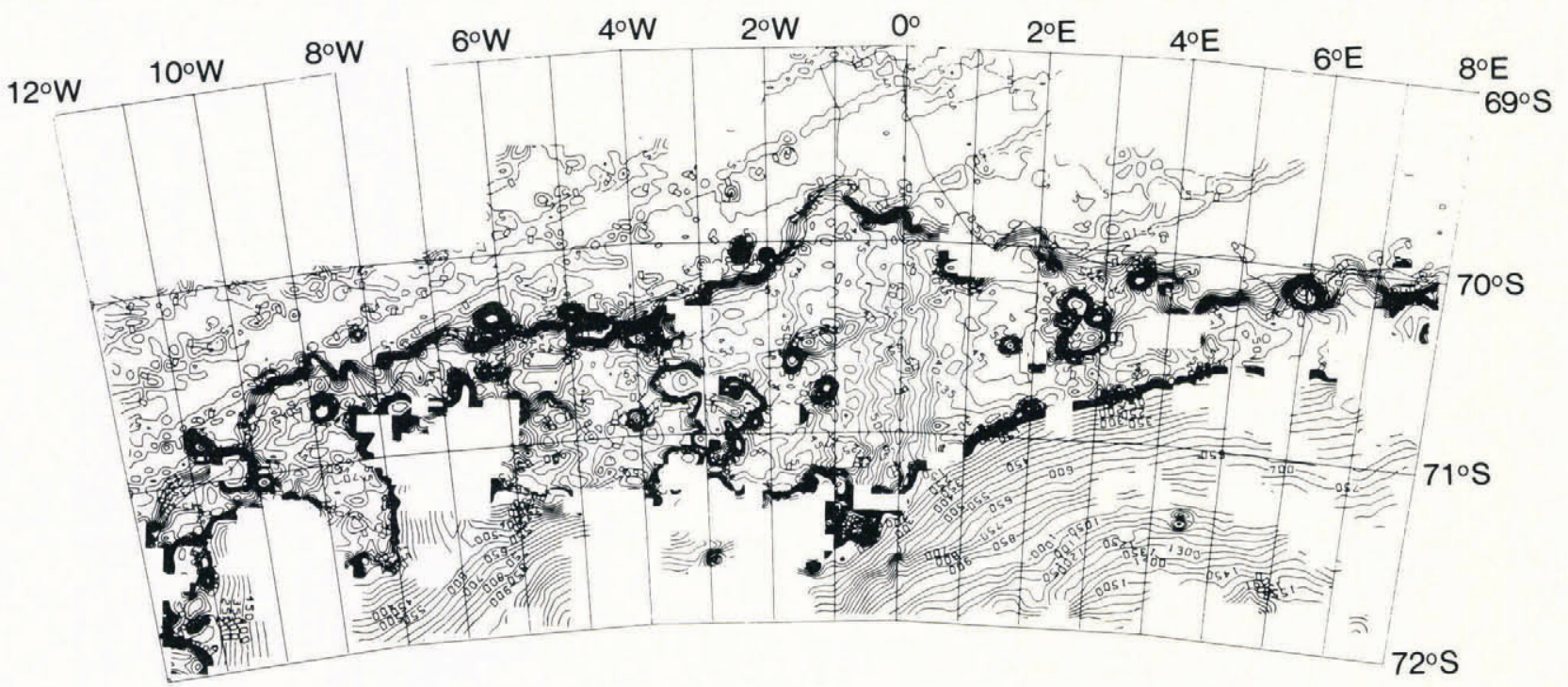

Fig.6. Surface elevations of Fimbulisen and adjacent grounded ice from Seasat radar altimetry showing Jutulstraumen ice tongue, ice rises, and other features discussed in the text.

the south-west. The error in these particular orbits appears to be about $5 \mathrm{~m}$, which is significantly larger than the approximately $1 \mathrm{~m}$ r.m.s. precision of the orbit calculations. The continuation of these linear orbit-error features is also seen on the ice shelf, but they are typically obscured by the larger relief observed on the ice shelf. Another error source is the data collected whenever a large change in elevation occurs and the altimeter is unable to maintain track of successive wave forms. Fig.lb illustrated this situation for a sea-ice/ice-shelf crossing. Some of these errors may remain in the data set as a result of incomplete visual editing of the re-tracked data or 3 sigma editing in the gridding procedure. One topographic high resulting from this second error source is located at lat. $70^{\circ} 50^{\prime} \mathrm{S}$., long. $01^{\circ} 10^{\prime} \mathrm{W}$.

Other features seen on Fig.6 are the ice front, several large ice rises, and the Jutulstraumen ice tongue (long. $0^{\circ} \mathrm{W}$.). The Jutulstraumen ice tongue is a ridge, $20 \mathrm{~m}$ above the surrounding ice shelf, which extends almost to the ice front. The enhanced lateral divergence expected for the ridge, compared to the surrounding thinner ice of the shelf, is observed in the gradual spreading of the contours as the ice tongue flows northward. Similar strong flow features are not observed on any of the other ice-shelf units, which is consistent with previous knowledge of this area.

A sketch map is made of features visible on unenhanced Landsat imagery (Fig.7). The Landsat imagery confirms the presence of large areas of grounded ice in the ice shelf, as indicated by the contours in Fig.6. The eastern half of the ice shelf is characterized by a series of small ice rises near the ice front. Most of these ice rises were originally mapped by Orheim (1978) using Landsat imagery and included in his contribution to the SPRI Antarctic Folio (Drewry 1983). The western part of Fimbulisen is divided by peninsulas of grounded ice, the boundaries of which are reasonably well represented by the contours in Fig.6, but the topography over the ice rises varies rapidly causing the altimeter to lose track. Also visible on the Landsat imagery is a zone of patchy blue ice south of the ice-shelf grounding line, which is represented by a line in the sketch map.

Examination of the altimeter wave forms indicates that

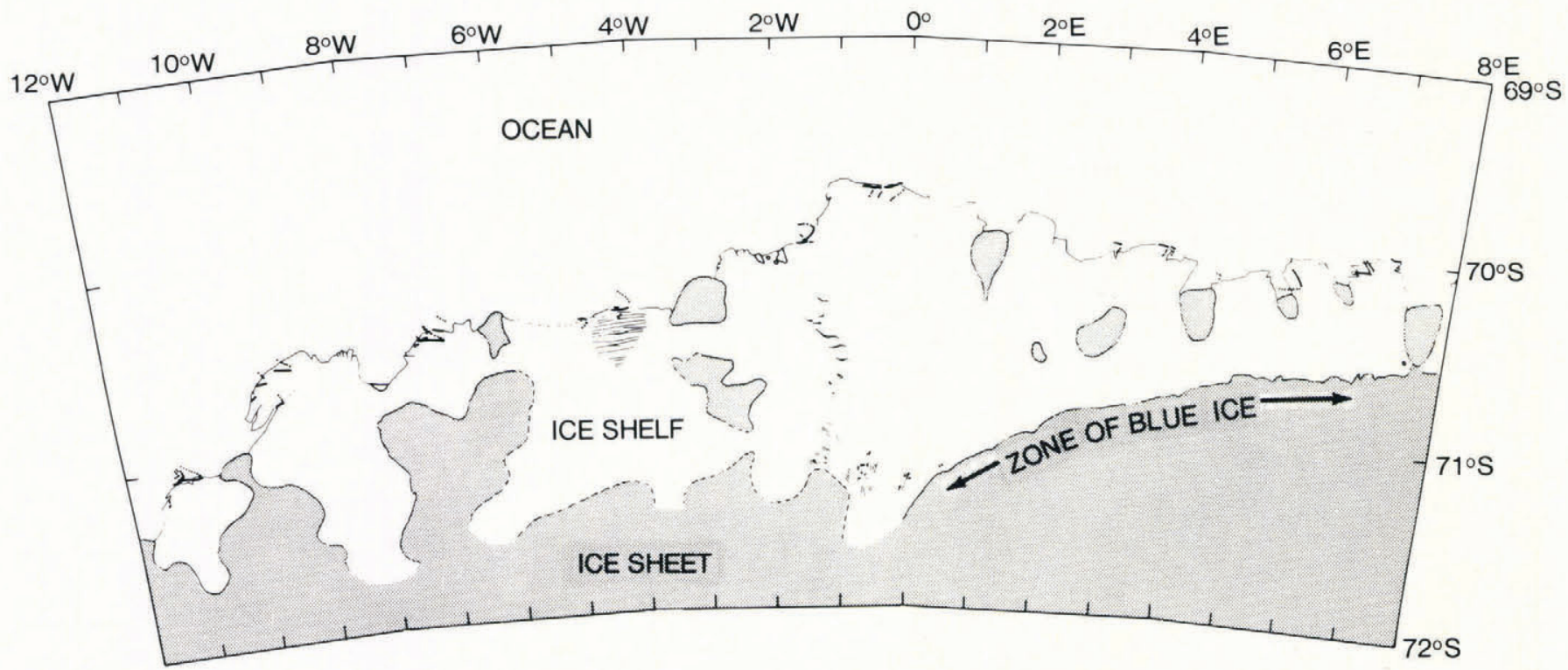

Fig.7. Fimbulisen ice front in 1978 derived from radar altimetry compared with ice front sketched from Landsat imagery taken in 1974. Also shown are ice rises, crevasse zones, and a line representing the northern edge of a zone of blue ice visible on the Landsat imagery inside the grounding line. 
valid elevations are obtained over at least some of the ice rises, and good elevation profiles can be obtained from the altimeter data set. However, the contours over the ice rises, as shown in Fig.6, are not good representations of the ice elevations, particularly those near the ice edge, because the gridding process is not designed to handle the sudden changes in surface height. Also, one example of a spurious elevation feature in the contour map appears around lat. $70^{\circ} 40^{\prime} \mathrm{S}$., long. $01^{\circ} 10^{\prime} \mathrm{W}$., in the vicinity of a crevasse zone by the Jutulstraumen ice tongue. Crevasse zones were first detected in the altimetry data on the Amery Ice Shelf by Partington and others (1987). In general, the altimeter continues to track strong reflectors after it has passed overhead, such as the rift in the ice shelf at lat. $70^{\circ} 40^{\prime} \mathrm{S}$., long. $09^{\circ} 30^{\prime} \mathrm{W}$. and the grounding lines of ice rises, for example, at lat. $70^{\circ} 18^{\prime} \mathrm{S}$., long. $02^{\circ} 40^{\prime} \mathrm{W}$.

\section{CONCLUSIONS}

The slant-range method of mapping sea-ice/ice-shelf boundaries has been applied to a systematic mapping of the Antarctic ice-shelf fronts north of lat. $72^{\circ} \mathrm{S}$. The method also applies to mapping at least some of the ice-sheet/seaice boundaries. At each satellite crossing of a boundary, a segment of the coastline up to about $10 \mathrm{~km}$ is mapped. Therefore, positions of parts of the seaward margin along the entire coastline north of lat. $72^{\circ} \mathrm{S}$. can be derived from Seasat radar-altimetry data. However, the density of Seasat coverage is limited by the short 3 month lifetime of the satellite, and positions are not obtained at every crossing. The method is also sensitive to icebergs embedded in the sea ice, to fissures near the ice front, and to the edge of fast sea ice. Consequently, the boundary of an ice shelf or the ice sheet is not always clearly determined.

About $40 \%$ of the Amery Ice Shelf front is mapped and about $10 \%$ of Fimbulisen. The accuracy in absolute position is estimated to be $\pm 1 \mathrm{~km}$. Comparison with features in Landsat imagery is especially useful for interpolating between radar-derived boundaries, for helping to resolve the left-right ambiguity of isolated radar-derived boundaries, and for distinguishing between ice fronts and other features such as fissures, icebergs, and fast ice. Therefore, information from the Landsat images should be incorporated into the mapping process. For Fimbulisen and the Amery Ice Shelf, there are some geodetic ground-control points, but for other areas the altimeter data can be used to provide control for Landsat or similar high-resolution imagery, provided the data are acquired at approximately the same period of time.

Comparison of the radar-derived ice front of the Amery Ice Shelf with the front on earlier Landsat imagery indicates an advance of the central part of the ice shelf with little or no calving between 1974 and 1978. Application of this method to the radar-altimetry data expected from subsequent satellite missions will be especially useful for monitoring the margin of the Antarctic ice shelves and seaward margin of the ice sheet.

The inner $200 \mathrm{~km}$ of the Amery Ice Shelf are shown to be an area with small mean slope and undulations, suggesting it is a zone of partial grounding similar to part of Rutford Ice Stream. On Fimbulisen, the ridge of a major ice tongue is mapped and several previously unmapped ice rises are evident in the radar data and the Landsat imagery. The radar altimeter provides profiles across some ice rises but, in other areas of crevasse zones or marked changes in surface elevations, special care must be taken to eliminate invalid elevations from the altimeter data set.

\section{ACKNOWLEDGMENTS}

We especially thank $\operatorname{Dr} \mathrm{R} S$ Williams for his kind assistance in helping us select the Landsat images from the files of the US Geological Survey and the SCAR photography library. Computer programming and data-analysis support has been provided by Anita Brenner, Judy Major, Yagyensh Pati, and Tom Martin of EG\&G Washington Analytical Services. Support for this work has been provided by NASA's Oceanic Processes Program and NASA's Climate Program.

\section{REFERENCES}

Bindschadler R A 1984 Jakobshavns glacier drainage basin: a balance assessment. Journal of Geophysical Research 89(C2): 2066-2072

Brenner A C, Bindschadler R A, Thomas R H, Zwally H J 1983 Slope-induced errors in radar altimetry over continental ice sheets. Journal of Geophysical Research 88(C3): 1617-1623

Brooks R L, Campbell W J, Ramseier R O, Stanley H R, Zwally H J 1978 Ice sheet topography by satellite altimetry. Nature 274(5671): 539-543

Brooks R L, Williams R S, Ferrigno J G, Krabill W B 1983 Amery Ice Shelf topography from satellite radar altimetry. In Oliver $\mathrm{R}$ L, James $\mathrm{P} \quad \mathrm{R}$, Jago $\mathrm{J}$ B (eds) Antarctic earth science. Cambridge, Cambridge University Press: $441-445$

Budd W F, Corry M J, Jacka T H 1982 Results from the Amery Ice Shelf Project. Annals of Glaciology 3: 36-41

Doake C S M, Frolich R M, Mantripp D R, Smith A M, Vaughan D G In press Rutford Ice Stream, Antarctica. Journal of Geophysical Research

Drewry D J 1983 Antarctica: glaciological and geophysical folio. Cambridge, University of Cambridge. Scott Polar Research Institute

Gundestrup N S, Bindschadler R A, Zwally H J 1986 Seasat range measurements verified on a 3-D ice sheet. Annals of Glaciology 8: 69-72

Martin T V, Zwally $\mathrm{H}$ J, Brenner A C, Bindschadler R A 1983 Analysis and retracking of continental ice sheet radar altimeter waveforms. Journal of Geophysical Research 88(C3): 1608-1616

Orheim O 1978 Glaciological studies by Landsat imagery of perimeter of Dronning Maud Land, Antarctica. Norsk Polarinstitutt. Skrifter 169: 69-80

Partington K C, Cudlip W, McIntyre N F, King-Hele S 1987 Mapping of Amery Ice Shelf, Antarctica, surface features by satellite altimetry. Annals of Glaciology 9: 183-188

ice-sheet margins from radar altımetry data. Annals of Glaciology 4: 283-288

Thomas R H, Martin T V, Zwally H J 1983 Mapping ice-sheet margins from radar altimetry data. Annals of Glaciology 4: 283-288

Zwally H J, Comiso J C, Parkinson C L, Campbell W J, Carsey F D, Gloersen P 1983[a] Antarctic sea ice, 1973-1976: satellite passive-microwave observations. Washington, DC, National Aeronautics and Space Administration (NASA Special Publication SP-459)

Zwally $\mathrm{H} \mathrm{J}$, Bindschadler $\mathrm{R} \mathrm{A}$, Brenner A C, Martin T V, Thomas R H 1983[b] Surface elevation contours of Greenland and Antarctic ice sheets. Journal of Geophysical Research 88(C3): 1589-1596 